\title{
DIFFICULTIES IN LEARNING THE PHONETICS OF THE CHINESE LANGUAGE, BASIC MISTAKES AND MEANS OF CORRECTION
}

\author{
G.I. Malyshev, I.E. Kiselevich, D.V. Selivanov
}

\begin{abstract}
This article reviews the main difficulties Russian-speaking students encounter while studying the phonetics of the Chinese language, the mistakes that are often made by them at the beginning of learning pronunciation, as well as ways of correcting those mistakes.
\end{abstract}

Keywords: Chinese, phonetics, students' mistakes.

\section{Introduction}

The process of learning a foreign language includes studying its four aspects: the phonetics, the vocabulary, the grammar and the stylistics. Learning these four aspects forms a student's skills of understanding and reproducing oral and written speech. In the case of Chinese, the phonetics is the part of the language to which both teachers and students should pay particular attention, because of the fundamental differences between the phonetic systems of Chinese and most Indo-European languages, as well as the specific relations between pronunciation and the meaning of the phrase being said in the Chinese language.

The topicality of this article is determined by the constantly growing and deepening economic and political connections between the Russian Federation and the People's Republic of China, which create a growing need for quality translation and interpreting work, and an interpreter's phonetic competence is of vital importance to their work.

The objective of this article is to describe the methods of correcting the basic mistakes made by Russian-speaking students while studying the phonetics of the Chinese language.

To achieve that objective, the following tasks should be completed: 1) describe the most common mistakes made by Russian-speaking students while learning pronunciation; 2) examine the main specifics of the phonetics of the Chinese language and the essential differences between it and the phonetics of the Russian language, which cause students to make mistakes; 3 ) examine the ways of correcting those mistakes.

The main unit of the phonological system of the Chinese language is a syllable, the structure of which is different from that in the Russian language. A syllable in Chinese, unlike in Russian, cannot consist of an arbitrary set of sounds. Instead, it comprises an initial (the consonant sound at 
the beginning of the syllable) and a final (the resting part of the syllable). The final can also be divided into a medial and a subfinal, which can, again, be divided into a central and a terminal [1: 8-11]. Because of the limited number of the initials and the finals ( 21 and 36 respectively) and the inability to combine them randomly, there is a finite amount of syllables in Chinese (421 in total) [2: 89].

The initials and the finals comprise certain sets of sounds, the articulation of a large part of which possesses two physiological characteristics, which often cause difficulties for Russian-speaking students: strong phonation breathing and tension in the speaker's vocal apparatus, which occurs in the process of pronouncing some of the phonemes, and which is much greater than in Russian. Some consonants in Chinese resemble certain consonants in Russian sonically, but differ from them in terms of manner and place of articulation. Apart from the specifics of the articulation, the consonant systems of the two languages are substantially different as well: there is no distinction between voiced and unvoiced, as well as between hard and soft sounds in Chinese, therefore the following vowel does not affect that criterion [3: 22-23].

Because of the limited abilities of expressing meaning with different combinations of sounds, the Chinese language evolved to have tones - certain shifts in the pitch of the speaker's voice that occur when pronouncing specific syllables, which are as important to the differentiation of a word's meaning as the pronounced syllable itself [1:15]. There is no concept of tone in the Russian language; however, every word has a stress. The stressed syllable is emphasized vocally and sounds longer than other syllables in the word. There is no concept of stress in Chinese, only certain phonetic positions, where the tone is pronounced most prominently [4: 9]; all the syllables in a word are pronounced in approximately equal time periods.

As can be inferred from the above, there are major differences between the phonetic systems of Russian and Chinese. These differences become a serious hindrance to Russian-speaking students learning the phonetics of the Chinese language.

The most common types of mistakes made by Russian-speaking students while learning the phonetics of the Chinese language are mispronunciation of the tones, mistakes with their length and prominence in specific positions in the flow of speech, mistakes with stresses, and also mispronunciation of certain sounds.

Mispronunciation of tones mostly occurs, because teachers do not spend enough time teaching their students the correct pronunciation of the tones and do not pay enough attention to their pronunciation later on in the learning process. A basic example of such a mistake is starting to pronounce the second tone with the wrong pitch: if it is too low, it resembles the third tone; if it is too high, it resembles the first [1:15-26]. To prevent the students 
from getting used to mispronouncing the tones, the teacher must make sure that they pronounce the isolated tones correctly, and only then progress to study more difficult parts of the phonetic system of Chinese. Studying the theoretical aspect of the tones can also help to better understand the correct pronunciation.

Mistakes with the length and prominence of the tones in specific positions in the flow of speech and mistakes with stresses occur because the concepts of tone and stress are incompatible. Russian-speaking students often try to replace the tones with stresses, which leads to them pronouncing some of the syllables in a word wholly and with a prominent emphasis and some of them more quickly and weakly, which is incorrect [5: 142]. To prevent such mistakes, it is necessary to explain the theory of the tones in Chinese to the students, and make them pronounce every syllable in a phrase equally long, which will help them learn to not stress any syllable in a word and pronounce all of them clearly. The employment of a systemic approach, taking account of all aspects of language learning, would be of particular efficacy in terms of furthering the desired aims [6].

Mispronunciation of certain sounds primarily happens because some phonemes that exist in Chinese are not present in Russian; however, there are differently articulated sounds that are sonically similar to the Chinese sounds in question. For example, the Chinese sound [c] is similar to the Russian [u], although the former, unlike the latter, is aspirated. There are also sounds, that do not exist in Russian at all, for example, the Chinese [r], commonly mistaken for Russian [p], is actually pronounced as something in between the combination [aыp] and the sound [ж]. The Chinese [i] does not soften the preceding consonant, and is articulated with more tension than the Russian [и]. Due to this, some students often mispronounce certain Chinese syllables, such as di and zi, trying to soften the initial [3: 22-23]. To avoid such mistakes, the teacher, as well as the student, should pay close attention to the differences between the articulation of the sounds and work to achieve the ability to pronounce them correctly.

\section{Conclusion}

In conclusion, the phonetical systems of the two languages in question have been examined and compared. The aspects of the Chinese phonetics, which are the most problematic for Russian-speaking students, have been determined and the most common and substantial mistakes, as well as means of correction and prevention, have been formulated based on them. If such issues are properly addressed, then language learning will be greatly improved. 


\section{References}

1. Speshnev, N.A.: Fonetika kitayskogo yazyka: uchebnoye posobiye [The phonetics of the Chinese language: the study guide] // Leningrad: Leningrad University publishing (1980). (In Russian)

2. Ilnitskaya, K.A.: Trudnosti $\mathrm{v}$ obuchenii russkikh studentov fonetike kitayskogo yazyka [Difficulties in teaching the phonetics of the Chinese language to Russian students] // Materials of the PSLU scientific-methodological conference (2015). (In Russian)

3. Bekhteva, N.N.: Trudnosti studentov pri izuchenii fonologicheskoy osnovy kitayskogo yazyka [Students' difficulties in studying the phonological basis of the Chinese language] // Materials of the PSLU scientific-methodological conference (2015). (In Russian)

4. Kubarich, A.M.: Semantika tona na kitayskom yazyke [The semantics of tone in the Chinese language] // Bulletin of Kemerovo State University. 4. (2012). (In Russian)

5. Xu, X.I.: Problemy prepodavaniya fonetiki kitayskogo yazyka russkim studentam [Difficulties in teaching Russian students the phonetics of the Chinese language] // Young Scientist. 12. p.2. (2011). (In Russian)

6. Mitchell, P.J., Mitchell, L.A.: Implementation of the Bologna Process and Language Education in Russia // Procedia - Social and Behavioral Sciences. V. 154. pp. 170-174. (2014)

\section{Information about the authors:}

Malyshev G.I. - student, Faculty of Foreign Languages, National Research Tomsk State University (Tomsk, Russia). E-mail: malysh@mail.ru

Kiselevich I.E. - student, Faculty of Foreign Languages, National Research Tomsk State University (Tomsk, Russia). E-mail: kissy@yandex.ru

Selivanov D.V. - lecturer, Department of the English Language for Natural-Science and Physical-Mathematic Faculties, Faculty of Foreign Languages, National Research Tomsk State University (Tomsk, Russia). E-mail: vobla7@rambler.ru 